\title{
Self-organized criticality in a model for developing neural networks
}

\author{
Benjamin van den Akker', Borja Ibarz ${ }^{2}$, Raoul-Martin Memmesheimer ${ }^{1 *}$ \\ From Twentieth Annual Computational Neuroscience Meeting: CNS*2011 \\ Stockholm, Sweden. 23-28 July 2011
}

Recent experiments have observed a dynamical state characterized by so-called neural avalanches in different neural systems, such as networks of cultured neurons [1], the developing retina [2] and the neocortex in vivo [3]. Neural avalanches are bursts of activity that have power-law size distribution, which suggests that the system has assumed a critical state. To investigate how such a state might develop, we study neural network growth models that were proposed on the basis of neurobiological experiments $[4,5]$. In these models, the spiking activity of a neuron governs the outgrowth of its processes and the spatial overlap between neuronal processes determines the coupling strengths. We show analytically that an appropriately modified version of these models self-organizes into a state where it generates critical spiking activity and neural avalanches, i.e. the network grows into criticality. The conditions under which this happens are studied analytically and numerically. We complement our findings by investigating the structural and dynamical properties of the network, such as the lengths of neural protrusions in different one- and two-dimensional spatial arrangements and the temporal correlations between avalanche shapes and sizes, during development and in the critical state.

\section{Author details \\ 'Department of Neuroinformatics, Radboud University, Nijmegen, 6525AJ, Netherlands. ${ }^{2}$ Center for Neural Science, New York University, New York, NY 10003, USA.}

Published: 18 July 2011

\section{References}

1. Beggs JM, Plenz D: Neuronal Avalanches in Neocortical Circuits. J Neurosci 2003, 23(35):11167-11177.

\footnotetext{
* Correspondence: r.memmesheimer@science.ru.nl

'Department of Neuroinformatics, Radboud University, Nijmegen, 6525AJ, Netherlands

Full list of author information is available at the end of the article
}

2. Hennig MH, Adams C, Willshaw D, Sernagor E: Early-Stage Waves in the Retinal Network Emerge Close to a Critical State Transition between Local and Global Functional Connectivity. J Neurosci 2009, 29(4):1077-1086.

3. Petermann T, Thiagarajan TC, Lebedev MA, Nicolelis MAL, Chialvo DR, Plenz D: Spontaneous cortical activity in awake monkeys composed of neuronal avalanches. Proc Natl Acad Sci U S A 2009, 106:15921-15926.

4. van Ooyen A, van Pelt J: Activity-dependent Outgrowth of Neurons and Overshoot Phenomena in Developing Neural Networks. J theor Biol 1994, 167:27-43.

5. Abbott LF, Rohrkemper R: A simple growth model constructs critical avalanche networks. Prog Brain Res 2007, 165:13-19.

\section{doi:10.1186/1471-2202-12-S1-P221}

Cite this article as: van den Akker et al: Self-organized criticality in a model for developing neural networks. BMC Neuroscience 2011 12(Suppl 1):P221.
Submit your next manuscript to BioMed Central and take full advantage of:

- Convenient online submission

- Thorough peer review

- No space constraints or color figure charges

- Immediate publication on acceptance

- Inclusion in PubMed, CAS, Scopus and Google Scholar

- Research which is freely available for redistribution

Submit your manuscript at www.biomedcentral.com/submit

\section{() Biomed Central}

C Biomed Central

(ㄷ) 2011 van den Akker et al; licensee BioMed Central Ltd. This is an open access article distributed under the terms of the Creative Commons Attribution License (http://creativecommons.org/licenses/by/2.0), which permits unrestricted use, distribution, and reproduction in any medium, provided the original work is properly cited. 